\title{
Reklamlarda Metaforik Öğelerin Kullanımı: Kozmetik Reklamları Örneği*
}

\section{Use of Metaphoric Elements in Advertisements: Cosmetic Advertising Example}

\author{
Dr. Öğr. Üyesi Bilge ÇAĞLAR
}

\begin{abstract}
$\ddot{O} \mathbf{z}$
Bu çalışmada reklam ve diğer pazarlama iletişimi çalışmalarında mesajı hedef kitleyle buluşturmak için sıklıkla başvurulan görsel metafor kavramı üzerine bir araştırma gerçekleştirilmiştir. Araştırmanın genel amacı, kozmetik reklamlarında kullanılan görsel metaforlarda saklanan yan anlamların neler olduğunu, bu anlamlama sürecinin hangi kodlarla oluşturularak hedef kitleye aktarıldığını ortaya çıkarmaktır. Bu anlamları ortaya çıkarmak için, Roland Barhes'ın düz anlam/yan anlam ayrımından yola çıkılmış ve reklamda görsel metafor literatürü incelenmiştir. Araştırmada model olarak kullanılan Phillips ve McQuarrie (2004)'in 9 kategoriye ayırdığı basılı reklamlarda görsel metaforlar tipolojisinden yararlanılmış, amaca yönelik örnekleme yöntemi ile belirlenen dergi reklamları incelenmiştir. Bu çalışmada, reklamlarda metafor kullanımına yönelik önceki çalışmalardan farklı olarak, görsel metafor türleri arasındaki ilişkiler ortaya çıkarılmaya çalışılmıştır. Araştırmada, görsel metafor içeren kozmetik reklamlarının altında yatan gizli, örtülü anlamları açığa çıkarılmak amacıyla göstergebilimsel yöntemden yararlanılmıştır.
\end{abstract}

Anahtar Kelimeler: Reklam, metafor, görsel metafor, anlamlama, göstergebilim

Makale Türü: Araştırma

\begin{abstract}
In this study, a research on the concept of visual metaphor, which is frequently used in advertising and other marketing communication studies, is used to bring the message together with the target audience. The general purpose of the research is to find out what the semi-meanings are stored in the visual metaphors used in cosmetic advertisements, and to find out which codes are created and transferred to the target audience. In order to reveal these meanings, Roland Barhes's sense of meaning / semantics has been examined and visual metaphor literature has been examined. In the study, Phillip sand and McQuarrie (2004) used the typology of visual metaphors in print ads that were divided into 9 categories. In this study, the relationships between the types of visual metaphors were investigated unlike previous studies. In this study, semiotic method was used to reveal the hidden, implicit meanings underlying the visual metaphor-containing cosmetic advertisements.
\end{abstract}

Keywords: Advertising, metaphor, visual metaphor, signification, semiotics

Paper Type: Research

\footnotetext{
${ }^{*}$ Bu çalışma yazarın doktora tezinden üretilmiştir.

${ }^{1}$ Gümüşhane Üniversitesi, İletişim Fakültesi, bcaglar@gumushane.edu.tr.
}

Atıf için (to cite): Çağlar, B. (2019). Reklamlarda Metaforik Öğelerin Kullanımı: Kozmetik Reklamları Örneği Afyon Kocatepe Üniversitesi Sosyal Bilimler Dergisi, 21(3), 995-1013. 


\section{Giriș}

Reklam, herhangi bir ürünü, fikri, hizmeti kısacası mesajlarını hedef kitleye iletmede en etkili iletişim araçlarından biridir. Reklamlar, ideolojinin aktarılmasında ve anlamın üretilmesinde önemli bir rol oynamaktadır. Reklamlar, kapitalist sistemin temelinde yatan değerlerin meşrulaştırılması açısından önemli bir yere sahiptir. Kurdukları anlamlar aracılı̆̆ıyla sözel ve görsel göstergeleri kullanarak tüketim kültürünü meşrulaştırmaya çalışmaktadır. Reklam, ideolojik ve kültürel yeniden üretimin gerçekleştiği bir alan olarak görülmekte ve toplumsal rollerin benimsetilmesi gibi bir amaca da seslenmektedir.

Günümüz koşullarında teknoloji imkânlarının da gelişmesiyle birlikte, her alanda olduğu gibi reklamcılık alanında da rekabet, öne çıkma, ürünü/firmayı farklılaştırma isteğinin ön planda olduğu yadsınamaz bir gerçekliktir. Firma sahipleri en kısa ve en etkili bir şekilde hedef kitlesiyle iletişime girme çabasındadır. İşte tamda bu noktada bu mesajların göndericileri olan reklam verenler, alıcı konumundaki taraf üzerinde, kendi hatırlanabilinirliğini, akılda kalıcılığını artırmak için adeta gizli bir dil gibi kullandığı göstergelerin gücünden yararlanmaktadır. Bu bağlamda da teknolojinin sunduğu imkânlardan da yararlanarak ilk olarak grafik tasarım çalışmalarına yönlenmektedirler. Grafik tasarım çalışmaları (afiş, el ilanı, broşür vs) iletişim edimini görebileceğimiz en etkili alanlardan biridir. $\mathrm{Bu}$ çalışmalarda iletişim edimini gerçekleştirmek daha yerinde bir ifadeyle hedef kitleyi etkilemek, eyleme geçirmek için farklı yöntemler kullanılmaktadır. Bunlardan başlıcaları görsel ve dilsel metaforlardır. Metaforlar görsel olarak resim ve fotoğraflarda yer alabilir veya sözlü olarak başlıkta, sloganda ya da metinde kullanılabilirler. Reklamın içindeki bu öğeler bize, orada bulunmayanı gösterir, orada olmayana gönderme yapar. Yani, metaforlar, orada bulunmayanın yerini alan orada bulunan şeylerdir. Düzanlamlı bir anlatım, genel olarak kelimenin, görüntünün tam ve gerçek anlamı üzerinde yoğunlaşırken, metafor dilin özel anlamları, yan anlamları kullanımlarıyla ilgilenir.

$\mathrm{Bu}$ çalışmaya temel oluşturan sorunsal, reklamcının metaforu neden tercih ettiği reklam hazırlarken kullanılan metaforun kullanım şekilleri, taşıdığı anlamları ve ne gibi özellikleri olduğudur. Çalışmanın uygulama bölümünde amaçsal örnekleme tekniğinden yararlanılarak örneklem içine alınan dergilerde yer alan kozmetik ürünlerin tanıtıldı̆̆ 1 ve yalnızca metafor içeren reklamların göstergebilimsel analizi yapılmıştır. Yapılan göstergebilim analiziyle, reklamların tüketicilere hangi örtülü anlamlar taşıyarak sunulduğu, asıl verilmek istenen örtük mesajların nasıl kurgulandığ gibi konular eleştirel bir gözle analiz edilmiştir. Bu analiz gerçekleştirilirken, Barthes'ın reklam-mit ilişkisinden yararlanılmıştır.

\section{Reklam ve Reklamda Anlam}

Endüstri devrimi, kitlesel seri üretim anlayışının ortaya çıkmasına neden olmuş, zamanla çok sayıda üretilen ürünlerin satışı ve pazarlamasında yaşanan problemler, işletmelerin rekabette üstünlük kazanarak rakipleri arasından sıyrllabilmek için, ürettikleri ürünler ve kurumları ile ilgili tanıtımlara, yani reklam faaliyetlerine önem vermelerini gerekli kılmıştır (Elden ve Yeygel, 2006: 2). Bu sebeple çağdaş pazar yapılarının önemli bir rolü olan reklam, gündelik yaşamın vazgeçilmez unsurlarından biri haline gelmiştir. McLuhan' a göre reklam, 20.yüzyılın mağara sanatıdır (Richards ve Curran, 2002: 63-77). Amacı doğrudan ve hızlı şekilde sonuç almak olan reklamlar toplum üzerinde de oldukça etkilidir. İnsanlar reklamlar aracılığıyla fikir sahibi olabilir, elde ettiği bilgiler aracılığıyla tutum ve davranış değişikliğinde bulunabilir. Bu sürecin işleyebilmesi için ise, hedef alıcıların reklamda iletilen mesajları doğru ve net şekilde anlamlandırması gerekir. Başka bir ifadeyle, reklam iletişiminde algılama ve anlamlandırma unsurları markanın konumlandırılması ve markayla arasındaki ilişkinin kurulması bakımından önemli bir husustur. 
Reklamlar, görsel olarak yansıttıkları bağlamda, açık ya da örtülü pek çok anlamı tüketicilere aktarmaktadır. Reklamda yer alan görsel unsurların, tüketici tarafından herhangi bir yorumda bulunmasına gerek kalmadan anlaşılan yönü reklamın düz anlamını; tüketicinin farkında olmadan ya da bilinçaltı yoluyla kaydederek edindiği bilgilerle aktarılan yönü ise reklamın yan anlamlarını ifade etmektedir (Elden ve Okat Özdem, 2015: 167). Düz anlam, göstergenin ortak duyusal, bilinen, açık anlamına gönderme yapar. Bir sokak manzarası fotoğrafı bize belirli bir sokağı gösterebilir; "sokak" sözcügünün bilinen anlamı binalardan oluşmuş bir şehir yoludur. Ama aynı sokak çok farklı biçimlerde fotoğraflanabilir. Renkli bir film kullanabilir, donuk bir gün ışığı seçilebilir, yumuşak bir odak ayarı yapabilir ve sokağı çocuklar için mutlu, sıcak, şefkat dolu bir oyun alanı haline getirilebilir. Ya da siyah-beyaz bir film, sert odak ayarı, güçlü kontrast düzenlemeler yapılabilir ve aynı sokağı oyun oynayan çocuklar için soğuk, zalim, barınılamaz ve yıkıcı bir mekân haline dönüştürülebilir. Bu iki fotoğraf, aynı saat diliminde ve birbirine yalnızca birkaç santimetre uzaklıkta iki fotoğraf makinesi tarafından çekilmiş olabilir. Bu iki fotoğrafın düz anlamsal anlamı aynı olacaktır, farklılığı yaratacak olan ise yan anlamlarıdır (Fiske, 2014:182).

Yan anlam, göstergenin, insanların duygularıyla ya da heyecanlarıyla ve kültürel değerleriyle bir araya geldiğinde oluşturduğu etkileşimini betimlemektedir. $\mathrm{Bu}$, anlamların öznelliğe ya da en azından öznelerarasılığa doğru kaydığı andır: bu anda yorum, yorumlayıcıdan etkilendiği kadar nesne ya da göstergeden de etkilenir. Barthes'e göre, yan anlamdaki en önemli koşul, ilk düzeydeki gösterendir. İlk düzeyin göstereni yan anlamın göstergesidir. Bizim hayali fotoğraflarımız aynı sokağın fotoğraflarıdır; aralarındaki farklılık, fotoğrafın biçiminde, görünümünde, yani gösterende yatmaktadır. Barthes yan anlam ve düz anlam arasındaki farklılığın en azından fotoğrafçılıkta belirgin olduğunu iddia eder. Düz anlam, fotoğraf makinesiyle çekimi yapılan nesnenin film üzerinde mekanik bir yeniden üretimidir. Yan anlam ise bu sürecin insani boyutudur: kadrajlamaya nelerin dâhil edileceğinin, odağın, 1şığın geliş biçiminin, kamera açısının, filmin kalitesinin ve benzerlerinin seçimidir. Düz anlam neyin fotoğraflandığıdır; yan anlam ise nasıl fotoğraflandığıdır (Fiske, 2014: 182-183).

Reklamların anlam özelliklerini irdelerken en önemli hususlardan biri, reklamın biçimi ne olursa olsun, önemli olan onun içeriğinde yer alan anlamın ne olduğunun bilinmesidir. Özellikle, farklı markalar arasındaki aynı ürünlerin niteliksel ayrımlarının giderek kaybolduğunu düşünürsek, tanıtımı yapılan ürün veya hizmet için aynı kategorideki diğer ürünle arasında fark yaratmak bir reklamın en önemli işlevlerindendir (Williamson, 2001: 24). Reklamlar bize sadece satılan ürün hakkında bilgi veren bir aracı değil, aynı zamanda o ürünün bizde anlam bulup, ifade ettiği şeyi satmaya çalışan bir araç konumundadır. Reklamcılık belli tip tüketiciler ile belli ürünler arasında bağlantı kurmakta ve nesnelerin dilini insanların diline dönüştürebilen sembolik bir yapı oluşturmaktadır.

\subsection{Postmodern Tüketim Kültürü ve Reklam}

Tüketim toplumu ve kültürünün bugün geldiği durumda en önemli etkilerden birini postmodernizm akımı yaratmaktadır. 1960'tan 1980'lere kadar geçen süre içerisinde resim, sanat ve mimaride kullanılan bu kavram, dünyadaki toplumsal ve siyasal dalgalanmalarla birlikte, yaşanan değişimin de etkisiyle felsefe, sosyoloji gibi disiplinleri de etkilemiştir. Küreselleşmenin etkilerinin çok hızlı bir biçimde hissedildiği bu dönemde, ekonomik performansların üretimde yeni stil arayışlarını tetiklediğini söylemek yanlış olmayacaktır. Konuya ilişkin dikkat çekici görüşlerden biri Michel Foucault'ya aittir. Foucault'ya göre, devlet yönetimlerinde değişimler yaşanmış ve sistemsel olan her şeyin yerini anarşi almıştır. Üretimde etkin rol alan yapıların yerleşiklik düzenden çıkıp göçebe ve hareketli düzene geçmesi öne çıkmıştır (Foucault, 1986: 22). Featherstone'un (2013) tüketim ve üretim ekseninde değişimlerin yaşandığ 1 yeni bir döneme geçildiğini vurgulayan postmodern dönem hakkındaki görüşü ise şöyledir: "Postmodern dönem, postmodern kültürün, kültürel malların ve pratiklerin üretimi, tüketimi ve dolaşımındaki daha kapsamlı değişimler dizisinin bir işareti ve habercisidir" Postmodernist teorisyenlerinden biri olan Jean François Lyotard ise 
postmodernizmi dönemsel bir farklılaşmayı ya da ayrılmayı ve yeni bir toplumsal düzenin doğuşu olarak görmektedir (Lyotard, 1977: 155). Bu dönemin, üretimin artıp ve kitleselleşmesine, ürünlerin alım satımında daha fazla insanın işleyişe dâhil olmasına, küreselleşme ve buna bağlı olarak sınırların ortadan kalkmasına, üretim şekillerinin değişmesine, tüketim şekillerindeki değişimlere ve gündelik yaşamın bu süreçlerden dolayı evrim geçirmesine neden olduğu söylenebilir (Kırılmaz ve Ayparçası, 2016: 47).

Tüketici ve ürünün farklılaştırmasını öngören postmodernist durum ve onun üretim biçimi içinde tüketici, sembolleri ve imajları hem tüketen, hem de üreten durumda konumlanarak aktif bir rol oynar. Tüketiciler ürünleri sadece fiziksel ya da işlevsel özelliklerinden dolayı değil, ürünlerin taşıdıkları imajları da satın alırlar ve tüketirler. Bu konuyla ilişkin olarak Bauman (1999), tüketim kültürünü, metaların parasal değerinin ortadan kalkması, ürünlerin yarar işlevi yerine gösterge işlevinin ön plana çıkması olarak tanımlamakta ve imrenilerek tüketilen şeyin göstergeler olduğunu belirtmektedir. Yine benzer bir görüşte olan Bauldrillard'ın meta-gösterge teorileştirmesinde (1975) ise, metaların kitlesel üretimi yönündeki hamlenin temel görünümü; kapitalizm koşullarında malların orijinal 'doğal kullanım' değerinin yanında mübadele değerine tabi kılınması metanın Saussure'cu anlamda gösterge sistemi içerisindeki konumu tarafindan keyfi olarak belirlenen bir gösterge haline gelmesidir. $\mathrm{Bu}$ bağlamda, tüketimin, kullanım değerlerinin tüketimi olarak, maddi bir fayda olarak değil, her şeyden önce göstergelerin tüketimi olarak anlaşılması gerekir (Featherstone, 2013: 152-153). Tüketim kültürü göstergeleri tüketmek olduğuna göre bu kültürün tipik özelliklerine bakmak gerekmektedir. Tüketim kültürü, tüketicilerin çoğunlukla statü arama, diğerleri arasında farklı olma, yenilik arama ancak bu yeniliğin da son model olması gibi amaçlarla ürün ve hizmetleri tutkuyla arzuladıkları, peşinde koştukları, ulaşmak için çalışıp çabaladıkları bir kültüre denk gelir. Bu kültür, çağımızın egemen kültürel biçimini gözler önüne seren doyumcul zevk arayışı, meta fetişizmi ${ }^{2}$, kullan-at, tutkular, alışveriş bağımlılığ 1 gibi tipik özelliklerden oluşmaktadır (Aytaç, 2006: 31).

Postmodern tüketim eylemlerinin belki de en önemli boyutu, kurgulanarak oluşturulmuş bir gerçeklik ve bu gerçekliğe katılmak yönündeki gelişmelerdir. Pazarlama ve reklam başta olma üzere her türlü iletişim çeşitleri ile yapılan ürün ve firma imajları, markalı ürünlerin ve mağazaların vazgeçilmez bir öneme sahip olmasına neden olmaktadır (Odabaşı, 2014: 105). Aydoğan'a göre (2009: 213), Türk insanı da hafta sonlarını ya "AVM'lerdeki tüketim ürünlerine "göz gezdirerek" ya da "kredi kartı taksitlendirmesiyle söz konusu ürün ve hizmetleri "sahiplenerek geçirmekte" ve böylelikle tüketim kültürünün bir parçası haline gelmektedir. Üniversite gençliğinin tüketim alışkanlıklarında ise moda, alışveriş merkezleri ve maruz kaldıkları reklamların etkisinin büyük ölçüde olduğu görülmektedir (Kaya ve Oğuz 2010: 154162). Moda, Marksist ideolojiye göre üst sinıfları etkiledikten sonra bu sinıflardan alt sinıflara doğru yayılan ve sürekli bir yenilik, farklılaşma ve taklit etme süreci içinde statü ayırımlarını sürdüren ya da yeni statü kazanmaya etken olarak kabul edilmektedir (Yanıklar, 2006: 38). Başka bir deyişle moda, toplumda var olan hiyerarşik düzenin sembolü olmuştur. Moda, bir bireyin yeniden üretilmesi, kimlik kazanım süreci, erkek veya kadın olmak noktasından hareketle cinsiyetçi algılamaları yaratan, din, ahlak ve ideoloji gösteriminin biricik ve tek göstergesidir. Moda ve reklam kavramlarının kültür endüstrisi ürünlerini ortaya çıkarmanın yanında önemli amaçlarından biri de, bu ürünleri benimsemeye, kullanmaya ve tüketmeye hazır tüketici tipi oluşturmaktır. Edilgen olarak kabul edilen izleyici durumundaki tüketiciler, radyotelevizyon, sinema gibi kitle iletişim araçlarında yer alan mesajlar yoluyla, kültür üretim sistemine ve onun amaçlarına uyum sağlamaya ikna edilirler (Odabaşı, 2013: 73-74).

\footnotetext{
${ }^{2}$ Marx'ın Kapital isimli eserinde üzerinde durduğu konudur. Meta fetişizmi, Metanın değerinin emekten kaynaklandığının unutulması, kapitalizmin ekonomik işleyişinin açık bir şekilde görülmesini engelleyerek onu olduğundan farklı göstermesi durumudur. Bkz. Eagleton, T. (1991), Ideology. London: VersoPress. Bireyler, metaları yaratırken ortaya koydukları emekleri unutarak onlara yabancılaşırlar. Metaların değerlerini büyüterek, metaların değerini ortaya koyan asıl değerin kendilerinin verdiği emek olduğunu görmezler. Metaların değerinin kendi doğasından kaynaklandığını düşünürler.
} 
Yukarıdaki açıklamalarla da belirtildiği gibi tüketim kültürü oluşumuna etki eden önemli olgulardan biri reklamdır. Reklamlar, ürünlerin tanıtımını yaparak satılması için uygulanan bir çalışmadır. Etkileyici cümleler, kısa ve öz anlatımlar, renk ve müziğin de bir araya gelmesiyle insanları harekete geçiren reklam, tüketimi tetiklemektedir. Kendi alanındaki kitleye ulaşıp ürünü almaya ikna etmek için potansiyel tüketiciler adına kişisel ve toplumsal bir kimlik kurgulamaya çalışan reklam, insanların arzu ve isteklerini tahrik ederek ihtiyaç duymadıkları ürün veya hizmeti satın almaya yönlendirerek savurganlığa ve gereksiz tüketime sebep olmaktadır (Güz, 2000: 139).

Kellner'a göre reklam bize, ürünlerin insanların daha mutlu, daha popüler ve daha başarılı olmasını sağlayacağını söylemektedir (Topçuğlu, 1996: 198). Kişinin daha iyi ya da daha mutlu bir hayat tarzı için arzuladığ 1 şeyler, bireylere sembolik bir anlatım aracı olan reklam yoluyla verilmektedir. Topçuoğlu'na göre Türkiye'de ve üçüncü dünya ülkelerinde reklamın en önemli işlevi, modern yaşam biçimlerinin propagandasını ve taşıyıcılığını yapmasıdır. Reklam, sadece bir tanıtım amaciyla yapılmamakta, aynı zamanda kurgu ve sembollerle yeni bir yaşam biçimi dayatmaya çalışmaktadır (Topçuoğlu, 1996: 202-203).

Reklam ve büyük mağazalar ile kent merkezlerinin 'rüya alemleri'ndeki malların teşhiri, daha önce üstü mühürlenip kapatılmış anlamları yok etmek ve ürünleri etkin bir şekilde yeniden adlandıran istisnai ve yeni bitişiklikler yaratmak için meta-göstergenin mantığından yararlanır. Sıradan ve gündelik tüketim malları lüks, egzotizm, güzellik ve cazibeyle ilintilendirilir ve bu esnada bu malların orijinal ya da işlevsel kullanımı giderek gözden yiter (Featherstone, 2013: 153). Bauldrillard genç kapitalist toplumda elektronik kitle iletişim araçlarının göstergelerin ve imajların dallanıp budaklanmasına, gerçek ve hayali arasındaki ayrımı silikleştirdiği bir simülasyon ${ }^{3}$ dünyasına yol açtığını belirtir (1983: 48). Kitle iletişim araçlarının özellikle de televizyon reklamlarının etkisiyle mesaj taarruzuna maruz kalan bireylerin, neyin ihtiyaç, neyin gerçek, neyin lüks olduğunu sorgulamadan tüketme eğilimine girdiklerini söylemek mümkündür. Reklamlar, tüketme eylemini prestij, imtiyaz, saygınlık, refah, kimlik oluşturma vb. eylemine dönüştürmektedir. Reklam yapay toplumsal konumlar oluşturarak, bireyleri, bedelini ödemek koşuluyla bu konuma sahip olacaklarına inandırır (Topçuoğlu, 1996: 181). Reklamlar ya da medya içerikleri, göstergelerin kendilerinden ziyade alt kodlarını tüketiciye empoze etmekle meşguldür. Her ürün, nesne olmanın haricinde farklı anlamları içinde barındırır. Kitle iletişiminde mesajların tamamında bireye yönelik mesajlar bulunmaktadır. Birey bu mesajları açar ve harekete geçer. Metin içeriğinin derinliği bireyleri tüketime doğru kaydırmaya başlar. $\mathrm{Bu}$ hareketlenme hali arzuların ve isteklerinin yerine getirilmesini sağlamaktadır. Kitle iletişim araçlarıyla her yanı sarmış olan elektromanyetik görüntü ve ses sinyalleri bireylerin arzularını durmaksızın üretir ve tüketir (Mutlu, 2005: 40). Özetle, Reklamlar aracılığıyla tüketicilere ne yiyip ne giymeleri, nasıl davranmaları, nerede gezmeleri gibi pek çok konuda bilgi iletilmektedir. Tüketiciler, kimlik inşasını, imaj, yaşam biçimi gibi olguları reklamlar aracılığıyla kendilerine iletilen bu mesajlar doğrultusunda şekillendirirler. Bazen bir ürün gerek olduğu için değil, sırf sağlamış olduğu sembolik imajla dahi tüketiciler tarafından satın alınabilir. Böylece, tüketici kendi sosyal rollerini tanımlarken, bu ürünlerin sembolik anlamlarından yararlanarak iletişim kurmaktadır. Bir başka ifadeyle, reklamlar özelde bir ürünü satarlarken genelde de tüketim değerlerini, hayat tarzını satmaktadırlar. Bu bağlamda, reklamlar, tüketicinin kendi düş dünyasında kurduğu fantezileri tüketim yoluyla gerçekleştirme imkânı verdiğinden dolayı, tüketicinin kendisine de bir tüketim metası olarak baktığını söylemek çok da yanlış olmaz. Aslında günümüzde bireyler, tüketirken, tüketiliyor da!

\section{Reklam ve Metafor İlişkisi}

\footnotetext{
${ }^{3}$ Bir araç, bir makine, bir sistem, bir olguya özgü işleyiş biçiminin incelenme, gösterilme ya da açıklanma amacıyla bir maket ya da bilgisayar programı aracılığıyla yapay bir şekilde yeniden üretilmesi” Bkz. Baudrillard, 1998. Simülakrlar ve Simülasyon. (Çev. O. Adanır). İzmir: Dokuz Eylül Yayınları.
} 
Aristo'dan Barthes'a, Richards'a McQuarrie'ye kadar dilbilimciler, göstergebilimciler, felsefeciler ve retorikçiler, anlamın bir parçası ve birer anlam oluşturucusu olan metafor ve türleriyle ilgilenmişlerdir. Her türlü dilde olduğu gibi, reklam dilinde de sıklıkla görülen ve retorik figürlerden olan metaforlar, bir şeyi kendi anlamından başka türlü, yönlerden benzediği bir başka şeyin adıyla kullanılmasıdır. Bununla ilgili olarak, dilbilimciler Sperber ve Wilson, metaforlar söz konusu olduğu zaman sözcükler ve anlatımlar arasında beklenmeyen ve sıradan olmayan benzerlikler kurulduğunu ifade etmektedirler. Düz anlamlı dil, geleneksel olarak kelimenin 'tam' ve 'gerçek' anlamını üzerinde taşırken, sözel metafor tüm diğer retorik öğeler gibi dilin özel kullanımları arasındadır. Tanıtımını yaptığı ürünün niteliklerini, reklamcı dolaylamasız ortaya koyabileceği gibi, onu ilgili olduğu başka bir nesne veya olguya benzeterek, benzetilen nesnenin tüm olumlu özelliklerini, tanıtımını yaptığı ürüne aktarmış olmaktadır (Bat1, 2007: 330).

Metaforların, reklamcılara çok sayıda imkânlar sundukları, yaratıcılığın sınırlarını genişlettikleri varsayılmaktadır. Reklamlar, insanların nispeten yapılandırılmış belli deneyim alanlarından etkili değerler ve karakteristik özellikler alırlar ve bunları reklamı yapılan ürüne aktarırlar (Forceville, 1996: 69). Reklam iletilerinde metaforların kulanım amaçları reklama karşı ilgiyi çekmek, reklamın hatırlanma düzeyini arttırmak, reklamda verilen mesajla ilgili olarak ikna durumunu arttırmak ve son olarak reklamı beğendirerek tüketiciyi satın alma davranışına yönlendirmektir. Burada önemli değişkenlerden biri, metaforların kullanım sıklığının ikna derecesine etkisidir. İzleyici ya da okuyucular, metaforları anlamlandırabilmek için ek bir bilişsel çaba harcamak durumunda kalabilir. Bir diğer değişken ise bunların metin içinde kullanıldığg bölümdür. Güçlü bir metin oluşturabilmek amacıyla, metafor metnin başlığı, yani sloganlar içinde ya da metnin sonuç kısmında kullanılmasının mesajın etkililiğinin arttığ görülmüsşür. Metaforlar aracılığıyla metin, okuyucu tarafindan gerçekleştirilen zihin aktivitesine girerek interaktif bir biçim almaktadır. Metinde yer alan sözcük öbekleri içinde bulunan kelimeler, başlangıçta tek tek sadece bir isim ya da fiil iken, daha sonra metaforlar aracılığıyla bir yerden ait olduğu uygun diğer bir yere aktarılmaktadır (Ramacetti, 1995: 114). Eğretilemelerde benzetilen öğenin mutlaka bilinir bir nesne ya da olgu olması gerekir. Bu gerçekleştirilmezse izleyicinin gerekli kod açımını yapabilmesi mümkün olmamaktadır. Böyle bir durumda, gönderilen iletinin anlamının çözülmesi çok güç olacaktır (Batı, 2013: 112-113).

Reklam mesajındaki anlamı kurgulamada, aktarmada ve çözümlemede kullanılan metaforlar, bir başka ifadeyle mesajın algılanarak, anlamlandırılması aşamalarında gerek dilbilimciler gerek göstergebilimciler metaforlardan yararlanarak, reklam iletişiminde, iletinin bir yap1, dizge olduğu ilkesinden yola çıkarak çözümlemeler gerçekleştirilmektedir (Küçükerdoğan, 2011: 176). Roland Barthes, reklam dilinin işleyişini ve bu dil aracılığıyla oluşan çağrışımları yorumlama işlemini şu şekilde açıklamaktadır; "İnsanlar, ürüne reklam dili aracılığıyla dokunurlarken, ona anlam verirler ve böylece de onun basit kullanımını zihin deneyimine dönüştürürler” (Barthes'dan Aktaran, Küçükerdoğan, 2005: 72). Metaforlar, bu anlamlandırma sürecinde zihinsel işleyişin sınırlarını zorlayan güçlü öğeler olarak karşımıza çıkarlar. Ang ve Lim (2006: 40), metaforların kültürel değerleri markaya aktarmanın öneminden yola çıkarak, basılı reklamlardaki metaforların, marka kişiliğinin algılanması ve markaya yönelik tutumu ne yönde etkilediği üzerinde çalışma yapmışlardır. Çalışma sonuçlarına göre, reklam başlıklarındaki ve kullanılan resimsel metaforların, sembolik ürün kategorisine oranla, faydacı (utilitarian) ürün kategorisinde daha etkili oldukları, metaforların yenilik, değişiklik enjekte ederek reklamı okuma ve işleme motivasyonunu artırdığ ve gizleme yeteneklerinin yer almasından dolayı reklama olan ilgiyi ve tüketici tarafından beğenilirlik düzeyini artırdığını ortaya koyarak metaforları hayal gücünün lokomotifi olarak değerlendirmişlerdir. Metaforlar aracılığ 1 ile deneklerde oluşan duygular ise, ürüne yönelik heyecan duyma ve ürünü daha sofistike olarak algılamadır.

Metaforlar doğası gereği bir şeyin diğer beklenmeyen bir şeye dayanarak anlatılması ve yaşanmasıyla ilgilidir; reklamdaki metaforik bir başlık ya da imajla karşılaşan tüketiciler mesajı 
değerlendirmek için var olan bilgilerini kullanacak; alışkanlık algılarını ve metaforun bağlamını merak edecektir. Sonuçta ise, tüketiciler metaforik reklam öğelerinden oluşan reklamla sahip markaları daha karmaşık algılayabilirler. Bunun yanında, metafor mesajı süsleyip gizlediği için marka gösterişli ve iddialı olarak algılanabilir (Mick, 1992: 413). Metaforlar günümüzün zor beğenen tüketicisini etkilemenin iyi bir yoludur. Doğrudan değil de dolaylı anlatımı seven, ürünün somut faydalarını hayalleri ve istekleriyle birleştiren tüketici metaforlara istediği anlamı katmaktan zevk duyar (Forceville, 1996: 35).

\subsection{Görsel Metaforun Anlamı Ve Reklamdaki Yeri}

Görsel metaforlar reklam mesajlarını iletmek için yaygın bir şekilde kullanılmaktadır. Reklamda kullanılan görsel metaforlar, izleyicinin mesaja daha fazla özen göstermesini, iletiyi anlayabilmek için reklamdaki ayrıntılara dikkat etmesini sağlar. Metaforların izleyiciyi ya da okuyucu ayrıntılara inmeye teşvik temel nedenlerinden biri, metaforik figürlerin olağan dışında oldukları ve bu bağlamda reklamda kullanılan bu figürler sapma olarak tanımlanır (McQuarrie ve Mick, 1999: 39-40).

Refaie "Görsel Metaforu Anlamak" isimli çalışması ile son yıllarda, görsel metaforun doğasına olan ilgiyi de teşvik edici olan, görsel biçimin çağdaş batı toplumundaki önemli rolü konusuna olan farkındalığın arttığını belirtmiştir. Reklâmlar, filmler, karikatürler gibi çok çeşitli tarzlar kapsamında görsel metaforların araştırıldığını ve yayınlardaki bu artışa rağmen araştırmacılar arasında temel terimler ve tanımlar konusunda çok az bir uzlaşma sağlanabildiğini belirtmiştir (Refaie, 2003: 77).

Forceville (1996: 35), reklamlarda görsel metaforu, beklenen bir görsel öğenin beklenmedik bir görsel öğe ile yer değiştirilmesi olarak tanımlamıştır. O'na göre metafordan söz edebilmek için, daha önceden var olan ve bir bağlantı olması gerekir. Örneğin, bir erkek gövdesinin gösterildiği ayakkabı reklamında; kravat olması gereken yerde ayakkabı kullanılmış ön plandaki nesne büyük ölçeklerde kullanışmış ayakkabıdır. Bu reklamdaki beklenmedik bir durum ise, ayakkabı normalde kravatın bulunduğu yere koyulmuştur. Burada izleyici, ayakkabı görselini olağan, düz şekliyle değil, kravat görseline dayanarak algılamaya davet etmektedir. Burada metafor "ayakkabı bir kravattır" şeklinde ifade edilebilir.

Caroll (1996) ise görsel metafor tanımlamasını, iki farklı alanının, görsel birleştirmeyle, uzlamsal olarak bağlanmış tek bir varlığa dönüştürülmesi durumuyla sınırlamıştır. Çalışmasında, FritzLang'ın Metropolis adlı filminden iki imajın üst üste bindirilmesiyle sunulduğu dev bir makinenin, canavara dönüştüğü sahneyi örnek olarak göstermiş̧tir. "Makine ve parçaları, Moloch isimli bir canavarın parçalarına dönüşmektedir. Buna rağmen, makine hala makine olarak tanınabilmektedir. Canavarın ve makinenin öğeleri tek bir figürde birlikte olarak sunulmaktadır" (Carroll, 1996: 814).

Gombrich (1971), bir portre karikatüründeki metafor kullanımını inceleyerek görsel birleştirmenin benzer bir biçimini tanımlamıştır. Örnek olarak bir politikacının kafasının bir hayvanın vücuduyla birleştirildiği karikatürü göstermiştir. Görsel birleştirmenin görsel metafor türlerinden birisi olmasının yanında bu tanımlamanın oldukça sınırlı olduğu söylenebilir.

Goatly'e göre (1997) görsel metaforlar sözlü metaforlarla karşılaştırıldığında; Carroll'un yaklaşımı mecazi terim ve gerçek kavramın bir arada sunulduğu A, B'dir şeklindeki açık metafora işaret etmektedir. Fakat sözlü metaforlarda bu kadar açılığa çok nadir rastlanmaktadır. Birçok görsel metafor örneği görsel birleştirme üzerine kurulu fakat daha örtülü biçimde yapılmaktadır. Görsel metaforların çoğu iki farklı öğenin bir öğe oluşturacak şekilde birleştirilmesi şeklinde değildir, çünkü genellikle iki öğeden mecâzi olan (araç) ya da genellikle ana öğe açıkça gösterilmemektedir (Goatly'den Aktaran, Çınar: 2009: 50).

Görsel metafor, ikna edici retoriğin sıklıkla çalışılan bir biçimidir (Phillips, 1997: 78). McQuarrie ve Mick (1996: 425), metaforun ilişkilendirilmesi beklenmeyen iki terim arasında benzerlikle oluştuğunu ve böylelikle yeni anlam ve imalar yarattığını savunmuştur. Bu görüşe 
göre metafor, sözcük anlamları birbirlerinden çok farklı olsa da; bir objenin mecazen diğer objeye benzediğini belirterek, iki objeyi kıyaslama yaparak karşılaştırmaktadır. Bir kere karşılaştırma yapıldığında, iki obje arasındaki benzerlik mantıklı olarak fark edilmeye başlanmaktadır (Stern, 1990: 71).

Retoriğin metaforik tarzı ve görsel şekli görsel metaforların önemli iki özelliğidir (Jeong, 2008: 60). Sopory ve Dillard'a göre metafor, iki farklı kavramın karşılaştırıldığı ve karşılaştırmadan dolayı bir kavramın özelliğinin diğer kavrama aktarıldığı retorik bir tarzdır (Sopory ve Dillard, 2002: 382). Görsel metaforlar dilsel metaforlara benzemekle birlikte görsel iknânın sözdizimsel yapısını kullandıkları için "görsel muhakeme" olarak da nitelendirilebilirler (Messaris, 1996: 10). Bu sebeple, görsel metaforlar sözlü metaforlara kiyasla daha dolaylı ve karmaşık olabilirler ve bu yüzden çeşitli muhtemel çıkarsamaların ortaya çıkmasına neden olmaktadırlar (Phillips, 2000: 16).

Dondis (1973), doğrudan, görsel metaforun içyapısına değinerek; ton, renk, çizgi, doku ve oran gibi bireysel unsurların önemine değinmiş ve bunların görsel yapısının sınırları içerisinde ya bir gerilim ya da bir uyum yaratma amacıyla görsel bir boşluk içerisinde nasıl akı1lıca ustalıkla işlendiğinden bahsetmiş̧tir. Dondis (1973), görsel yapıların, görsel iletileri taşımak için nasıl oluşturulduğunu ortaya koymuştur. Metaforlar, olayları normal algılama şeklimizi genişletir ve çok farkı bireysel anlamlar ortaya koyabilir. Görsel metaforlar, örneğin, s1k sık, soyut fikirleri temsil etmek için somut objeleri kullanır. Metaforlar, ayrıca, metaforik anlamda gizli kalmış belirsizlikler yardımıyla alıcının şaşırmasını sağlamayı amaçlar. Leiss ve arkadaşları (1986), metaforun, modern reklamcılıkta kullanılan temel iletişim şeklinin tam kalbi olduğunu ileri sürmüşlerdir (Aktaran: Ang ve Lim, 2006: 39).

Görsel metaforlar hakkında temel anlamda bazı araştırmalar yapılmış da olsa (Carroll, 1996; Forceville, 1994, 1995, 1996; Morris, 1993) görsel metaforların nasıl anlaş1lması gerektiği ve sözlü metaforlardan hangi biçimlerde ayrıldığı hakkında tartışmalar günümüzde de devam etmektedir.

\section{Elle ve Cosmopolıtan Dergilerinde Yer Alan Reklamların Göstergebilimsel İncelemesi}

\subsection{Araştırmanın Amacı}

İçerisinde bulunulan yüzyılda reklamlar bireyleri tüketime yönlendirme noktasında en önemli araçlar olarak ortaya çıkmaktadır. Bu noktada çok sayıda metaforu barındıran reklamlar birtakım yöntemlerle kişilerin ilgisini çekme yoluna gitmektedir ve bu yöntemlerin en başında grafik tasarım çalışmaları gelmektedir. Bu çalışmanın amacı, başta kadınlar olmak üzere, herkes tarafından takip edilen ve bir grafik tasarım çalışması olan kozmetik modası reklamlarının sahip olduğu görsel kodlar ve bu kodlarla (anlatım öğeleri) verilmeye çalışılan mesajları göstergebilim aracılığıyla incelemektir.

\subsection{Araştırmanın Yöntemi}

Çalışmada reklamlarda kullanılan görsel metaforların taşıdıkları anlamların grafik tasarım çalışması kapsamında inceleniyor olması, uygulamada göstergebilim yönteminin kullanılmasını gerekli kılmıştır. Göstergebilim, bilimsel bir yöntem olarak yapısalcılığın en etkin biçimde uygulandığı disiplinlerden biridir. Yapısalcılar, gösterge sistemlerindeki yüzeyde görüneni değil, altındaki derin yapıları araştırır.

\subsection{Araştırmanın Evreni ve Sınırlılıklar}

Çalışmanın evrenini tüm moda dergileri olup, bu dergiler arasından en çok satan Elle ve Cosmopolitan dergileri çalışmanın örneklemini oluşturmaktadır. Dergilerde yer alan moda reklamları çözümlenirken bilimsel bir çözümleme yöntemi olan yapısalcı ve göstergebilim yönteminin getirdiği 'amaçsal seçme' yöntemi ile örneklem oluşturulmuştur. Bu yöntemde araştırmacı kendi yargılarına ve edindiği bilgilere göre araştırmanın amacına en uygun 
düşündüğ̈̈ örneklemi seçer. Burada amaç, araştırmanın problemine cevap bulunacağı inancıdır (Altunışı ve arkadaşları, 2010:141). Bu sebeple, örneklem olarak seçilen Elle ve Cosmopolitan dergileri içinde yer alan ve metafor içeren kozmetik modası reklamları incelenmiştir. Seçilen dergilerde Eylül 2016 - Haziran 2017 sayılarında yer alan kozmetik modası içeren reklamlar belirlenmiş̧; bu dergilerde toplamda 127 adet kozmetik reklamının yer aldığı ve bunlar içerisinde 54 reklamın metafor içerdiği saptanmıştır. Her iki dergide de aynı reklamın dergilerin aynı ya da farklı sayılarında verildiği görülmüştür. Bu reklamlarda toplam ve metafor içeren reklamlar sayısının belirlenmesinde değerlendirilmiştir.

Çözümleme bölümünde ele alınan moda reklamları; yukarıda da belirtildiği gibi seçilen dergilerdeki kozmetik modası reklamları ile sınırlandırılarak inceleme yapılmıştır. Bu reklamlar, öncelikle bir bütün olarak ele alındıktan sonra reklamlarda yer alan görsel ve dilsel öğeler ayrı ayrı değerlendirilerek özelliklerine, biçimi altında yer alan anlamına -bulunduğu toplumun kurallarına göre- ve diğer öğeler ile oluşturdukları ilişkilere göre incelenmiştir. Bu aşama gerçekleştirilirken Barthes'ın 'Çağdaş Söylenler'deki göstergebilimsel yaklaşımı temel alınmıştır. Reklam metinlerinde yer alan sözel ve görsel göstergeler bir arada yorumlanıp, yan anlamlarla kurulan mitler ortaya çıkartılarak anlamın nasıl kurulduğuna, göstergelerin birbirleriyle olan iliş̧kilerine, şifrelenen görüntüsel iletinin (metaforun) ne amaçla kullanıldığına bakılmıştır. Ancak Roland Barthes'ın daha sonraki çalışmalarında belirttiği gibi görsel göstergeler tek başlarına anlam oluşturmadıkları için, reklamlarda kullanılan görsel göstergeler yanlarında yer alan metinle beraber yorumlanmıştır. Bu inceleme doğrultusunda, Philips ve McQuarrie'nin 2004 yılında gerçekleştirdiği, dokuz kategoriye ayrılan basılı reklamlarda görsel metafor tipolojisinden de yararlanılmıştır.

\subsection{Reklam Analizleri}

Çalışmanın bu bölümünde örneklem olarak seçilen dergilerde yer alan ve metafor içeren reklamların göstergebilimsel analizleri yer almaktadır. Tez çalışmasında toplamda 20 reklam analiz edilmiş olup burada 5 reklam analizine yer verilmiştir.

\subsubsection{Pastel Reklam Analizi}

Şekil 1. Pastel reklam

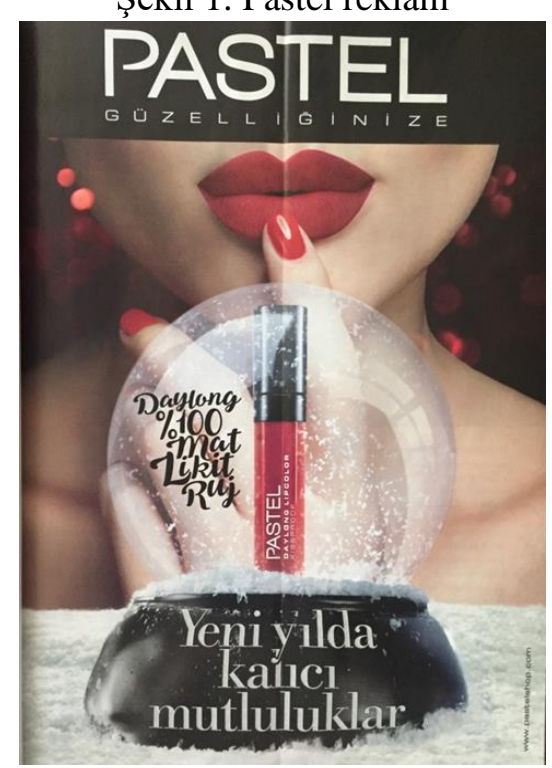

Gösterenler: Reklam, Cosmopolitan dergisinin Aralık 2016 sayısında yer almaktadır. Reklamda bulunan gösterenler şunlardır; Reklamın başlığı, slogan, metin, web adresi, siyah

\footnotetext{
${ }^{4}$ Detaylı bilgi için Philips ve McQuarrie'nin “Beyond Visual Metaphor: A New Typology of Visual Rhetoric in Advertising” isimli çalışması incelenebilir.
} 
şerit, kar küresi, ruj, kadın imgesi ve zeminin bir bölümü kaplayan kar. Reklamda yüzünü göremediğimiz kadın figürü görülmektedir. Reklam, bir ruj tanıtımı olduğundan ötürü, kadının yalnızca dudak kısmı gösterilmektedir. Aynı zamanda içinde rujun yer aldığı bir kar küresi vardır. Reklamda ağırlıklı olarak kullanılan renkler siyah ve kırmızıdır.

Gönderge Sistemleri: Güzellik, kalıcı güzellik.

Mit: Kalıcı bozulmayan güzellik miti.

Reklamın Philps ve McQuirre'in Tipolojisine Göre Metafor Türü: Görsel figürlerin bağlantısı kategorisinde yer alan, birleştirme metaforu kullanılmıştır. "Ruj, kar küresiyle ilişkilidir" şeklinde formüle edilmiş, ruj ve kar küresi öğeleri imaj içerisinde birleştirilerek kullanılmıştır.

Analiz: Reklamı yapılan ürün mat rujdur. Reklam derginin Aralık ayında, yani yılbaşına girildiği ayda yapıldığı için reklam sloganında "Yeni yılda kalıcı mutluluklar" ifadesi yer almaktadır. Okuyucuya bu rujun kalıcı olduğu vaadi reklam sloganında verilmiştir. Bununla birlikte, "yeni yılda kalıcı mutluluk istiyorsanız, bu ürünü kullanın" mesajı da verilmektedir. Rujun özelliğine de reklamda değinilmiştir. "\%100 mat likit ruj” ifadesi ile rujun hem likit hem de mat olduğu anlaşılmaktadır. Bu da demektir ki, ruj likit olduğu için kolay sürülebilmekte. Barthes, 'Çağdaş Söylenler'de düz anlamın ilk, doğal, görünen anlam olduğunu belirtmiştir. Yan anlam kavramını ise metinlerde gizli olan anlamı açıklamak için kullanmıştır. Barthes düz anlamsal düzeyin doğal anlam olduğunu, yan anlamı ise ikincil, ideolojik anlamı ifade etmekte kullanıldığını ve mit olarak işlev gördüğünü belirtmiştir. Bu mitler de, toplumsal düzeni doğallaştırıcı, meşrulaştırıcı bir rol oynamaktadır. Barthes, yan anlamın kültüre göre şekillendiğini ve bu bağlamda kodlandığını öne sürmektedir. Göstergeler ve kodlar değer yargıları içermektedirler (Barthes,1996: 198). Bu bağlamda reklamın görsel metafor analizine bakıldığında; kar küresi içerisinde tanıtımı yapılan rujun yer aldığı görülmektedir. Bu görselle okuyucuya/hedef kitleye "bu ruju kullanırsanız nasıl ki kar küresi içerisinde yer alan objelerde bozulma veya benzeri bir durum yaşanmazsa aynı şekilde rujda da herhangi bir dağılma bozulma olmaz, kalıcı bir ruj olur" mesajı verilmektedir. Bu mesaj oluşturulurken görsel kodlardan (kar küresi-ruj) yararlanılmış ve reklamın yan anlamını asıl iletilmek istenen mesajı bu kodlar aracılığıyla verilmiştir. Buradaki görsel metafor, kar küresi aracılığıyla ruja yüklenen koruyucu, bozulmayan, kalıcı anlamlarıdır. Reklamda aynı zamanda güzellik miti de kullanılmaktadır. Markanın isminin hemen altında "Güzelliğinize" ifadesi ile anlamlandırmanın güzellik miti üzerinden yapıldığının göstergesidir. Pastel marka ürünleri kullandığınızda güzel olacağınızı, markanın okuyucuya ürünleri kullanıldığı takdirde güzellik vaat ettiğini söyleyebilir. Reklamda kullanılan görselle (dolgun kadın dudağı) de bu vaat desteklenmektedir. Buradaki mit, "Pastel ürünleri kullanarak güzel olabilirsiniz" işlevini yerine getirmekte, ruju kullanarak da ayrıca "kalıcı mutluluğa sahip olabilirsiniz" mesajı iletilmektedir. Ayrıca reklamın, arka planda hâkim olduğu siyah zemin üzerinde kırmızı renkte 1şıktılar görmekteyiz; bu kullanımda tüketiciye bu marka/ürün kullanıldığı takdirde fark edileceği, parlayacağı mesaj1 da iletilmiştir. Dyer (2010: 445) reklamın tüketiciye mallar ve hizmetlerle ilgili bilgi vermekten çok, toplumsal değerler ve tutumlarla ilgili bir toplumsallaşma işlevi gördüğünü savunur. $\mathrm{Bu}$ reklamla birlikte okuyucuya, bu markanın ürünlerini kullanırsanız, güzel olursunuz ve toplumda daima güzele rağbet vardır. Böylelikle bir imaj değeri kazanmış olursunuz. Reklamlar, bu gibi mitler aracılığıyla tüketim kültürünü beslemektedirler. Bir ürün satın alınırken, ürünün kişiye sağlayacağı imaj düşünülmektedir artık. Reklamın grafik tasarımsal düzenine baktığımızda ise, siyah ve kırmızının ağırlıkta olduğu renkler tercih edilmiştir. Siyah; asil, resmi bir renktir. Markanın isminin yazılı olduğu siyah şeritle hem marka adı ön plana çıkartılmış, hem de markanın asil bir duruşa sahip olduğu iletisi yan anlamsal anlam olarak karşımıza çıkar. Slogan (yeni yılda kalıcı mutluluklar) yapımında kullanılan beyaz kar efektiyle de yeni yıla gönderme yapılmıştır.

Reklamın görsel zemininde (kar küresinin zemininde) yer alan karlar yazılı metinde vaat edilen kalıcı, bozulmayan, geçmeyen; yani ürünün eğretilemesidir. Bu görsel ile nasıl ki 
yiyecek ve içeceklerimizi soğukta buzdolabında saklarsak bozulmaz, burada da kullanılan kar görselliğiyle ürünün özelliği olan "kalıcı"lığına gönderme yapılmıştır.

Yapılan analiz doğrultusunda reklamlar özelde bir ürünü satarlarken genelde de tüketim biçimlerini, hayat tarzını satmaktadırlar. Reklamın tüketim ideolojisini taşıdığ 1 nokta tam da budur aslında. Reklamlarda tüketicinin ürünü kullanmasıyla birlikte yaşamlarının değişeceğini ve kişiliklerinin de farklı olacaklarını düşünecekleri iletiler sunulmaktadırlar. Geleneksel değerler idealize edilerek, olumsuzluklarından arındırılarak reklam metinlerinde kullanılmaktadır (Dağtaş, 2003: 88). Reklamın ideolojisiyle tüketicide "zatenlik" hissi yaratılmaktadır. "Zatenlik hissi o gruba ait olmak için o ürünü satın aldığınızı değil, zaten satılan ürünün hitap ettiği bir gruba ait olduğunuzu zannettiğiniz ya da bildiğiniz için o ürünü aldığınızı düşündürtmektedir (Wiliamson, 2001: 48). Reklamlar hedef kitleye özgür seçim hakk1 sunduğunu yansıtmaktadır, fakat özünde bu durum çok farklıdır. Hedef kitle üzerinde 'zaten' bulunan değer yargılarına seslenerek tüketicilere özgür seçim yapmışlar yanılsamasını vermektedir. Reklamların tüketici üzerindeki kontrolü de bu ideolojik işlev sayesinde yürümektedir. Bunun sonucunda tüketici, kendi özgür iradesiyle satın almaya karar verdiğini düşünerek yaptığı şeyin altındaki örtülü gizli olan ideolojiyi fark edememektedir. Oysaki reklamlar ideolojiler ve mitler aracılığıyla bezendiğinden dolayı yeni bir anlam yaratılmış gibi görünmez, zaten o anlamı bildiğimiz bize hissettirilerek seçim yaparken kendi kararımızın seçimi olduğu düşündürülür.

Reklam metinleri oluşturulurken, kültürel değerlerimizin ve toplumsal etkileşimlerimizin sembolleri ve fikirleri kullanılmaktadır (Dağtaş, 2003: 87). Toplum tarafından iyiye, güzele daima rağbet olduğu için, yukarıda incelenen reklamda da 'güzellik miti'nin ne amaçla kullanıldığı aşikârdır. Güzel olmak için, güzellikte kalıcılığı yakalamak için bu markayı bu ürünü kullanın ki sizde toplumda yer edinin ideolojisi örtük olarak reklamda verilmemektedir. Bu doğrultuda da, aslında bu şekilde örtük bir ideolojiyi içinde barındıran, toplumun değer yargılarına seslenen, bu değer yargıları tüketiciye vaat eden reklamların kapitalizme hizmet eden önemli bir tüketim aracı olduğu yadsınamaz bir gerçek olarak çıkar karşımıza. Reklamlar, ürünün kullanım fonksiyonundan ziyade bu ürünü kullanırsanız şöyle bir imaja sahip olursunuz fikrini tüketicilere iletmektedirler. Özetle tüketiciler reklamlar aracilığıyla inşa edilen göstergeleri, kimlik sistemlerini tüketmektedirler.

\subsubsection{Burt'sBees Reklam Analizi}

Şekil 2. Burt'sBees reklam

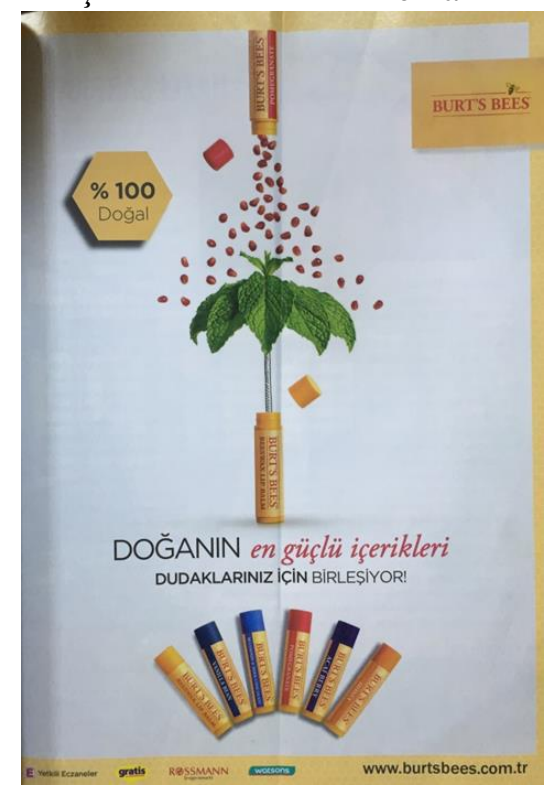


Gösterenler: Reklam, Cosmopolitan dergisinin Aralık 2016 sayısında yer almaktadır. Reklamda bulunan gösterenler şunlardır; Reklamın sloganı, metin, web adresi, sarı bal peteğinden oluşmuş şeritler, ürün görseli, yapraklar, logolar ve beyaz zemin. Reklamda ağırlıklı olarak kullanılan renkler beyaz ve sarıdır. Bu tercihin firmanın kurumsal renginin sarı olmasından kaynaklandığ 1 söylenebilir.

Gönderge Sistemleri: Doğal, katkısız, güçlü içerikler.

Mit: Doğallık miti.

Reklamın Philps ve McQuirre'in Tipolojisine Göre Metafor Türü: Görsel figürlerin bağlantıs1 kategorisinde yer alan, birleştirme metaforu kullanılmıştır. "Dudak koruyucu krem, doğanın içinde bulunan yapraklarla doğayla ilişkilidir" şeklinde formüle edilmiş, ürün ile benzettiği nesne birleştirilmiştir. Ürüne bu benzetim aracılığıyla doğadan, doğal özelliği aktarılmıştır.

Analiz: Reklamı yapılan ürün dudak koruyucusudur. Reklamın sloganı "Doğanın en güçlü içerikleri dudaklarınız için birleşiyor" ifadesidir. Okuyucuya bu dudak koruyucusunun doğanın en güçlü ürünlerinden yapıldığı, ürünün doğal olduğu vaadi bu sloganda verilmiştir. Ürünün özelliğine de reklamda değinilmiştir. "sarı altıgen üzerinde yer alan \%100 doğal" ifadesinden ürünün doğal maddelerden yapıldığının üzerinde durulmuştur. Marka adı "Burt'sBees (Burt'ün Arıları)", kurucusu Roxanne Quimby ve arı yetiştiricisi BurtShavitz'dir. Marka adı arıcılıktan geldiği için \%100 doğal ifadesi de arı peteğini anımsatan sarı altıgen üzerinde verilmiştir. Aynı zamanda benzer sebeple reklam etrafını çevreleyen sarı şeritlerin zeminlerinde de arı peteği dokusu yer almaktadır. Hall, içeriklerin düz anlamlarının kapalı kodlarla oluşturulduğunu, yan anlamların ise, çok anlamlılık barındırdığını ifade etmiştir (Hall, 2005: 86). Bu doğrultuda kullanılan görsel öğeler incelendiğinde; Arıcılık, bal üretimi doğal bir yöntem olduğu için yine bu göstergeler aracılığıyla markanın ürünlerinin doğal olduğu anlamı yaratılmıştır. Reklamın sloganı içerisinde yer alan 'doğanın en güçlü içerikleri' ifadesinde 'en güçlü içerikleri' sözcüklerinde kırmızı renk kullanılıp, bu konuda markanın iddia ettiği vaadi güçlendirmek için bu sözcüklere vurgu yapılmıştır. Reklam görseline baktığımızda sayfanın alt bölümünde ürünün çeşitlerini görmekteyiz. Ürünlerin farklı renklerde olması da aynı ürünün farklı özelliklere sahip olduğunun bir göstergesidir. Bu farklılık renkler aracılığıyla ve ürünler üzerinde yer alan ifadeler aracıllğıyla verilmiştir. Reklamın ana görselinde ise, dudak koruyucusu ürün, yapraklardan oluşan bir ağaç ve ağacın üzerinde bulunan yine aynı ürün içerisinde dökülen nar taneleri yer almaktadır. Bir sembolün, bir göstergenin anlam taşyyabilmesi için tüketicinin içinde yer aldığı toplum, kültür tarafından bu sembolün bilinmesi gerekmektedir. Kültürün genişliği göstergelere yüklenen anlamı da çeşitlendirmektedir. Bu reklamda yer alan nar tanelerinin, hem ürünün vaadi olan doğallık mitine hem de nar ya da nar çekirdeğinin ve suyunun cilt bakımında çok iyi bir antioksidan kaynağı olduğunun bilinmesidir. Ayrıca narın B5 ve $C$ vitaminleri bakımından oldukça zengin olduğu da bilinmektedir. Kültürümüzde narın cilde faydalarıyla ilgili birçok makale, haber yayınlanmış olup narla ilgili bilgi sahibi olduğumuz da hesaba katılarak ürün görselinde nar taneleri kullanılmıştır. Odabaşı'na göre (2013: 86) reklamın kültür dünyasından alıp ürün ve markaya yüklediği anlamın, tüketiciler tarafından yorumlanmasi ve kabul edilmesi sonucunda, reklamın kendisi de yaşayan bir kültürel ürüne dönüşmektedir. Yaratılan kültürel anlamlar markalara aktarılarak markalar, kimliğin inşasında ve sürdürülmesinde sembolik kaynaklar olarak kullanır duruma gelmektedir. Böylelikle bu üründe kullanılan görsel öğeler aracılığıyla doğal, katkısız, zararsız ürün olduğu miti aktarılmıştır. Bu ürünü kullandığımız takdirde herhangi bir yan etkisini göremeyeceğimizi çünkü doğal bir ürün olduğunu kullanılan öğelerle desteklemiştir. Aynı zamanda ana görselde kullanılan, ağaç figürü de yine ürünün doğallığına gönderme yapmaktadır. Yukarıdan aşağıya ürün içerisinden dökülen nar taneleri yine ürün içerisinde yer alan doğal yaprakları olan ağaçla birleştirilmiştir. Doğanın özellikleri ürüne atfedilmiştir bu yolla. Yukarıda da değindiğimiz gibi bu bir metafordur. Burada birleştirme metaforu kullanılmış ve bu yolla doğallık miti bir kez daha tüketiciye aktarılmıştır. Levi-Strauss'dan hareket eden Chapman ve Egger, reklamlarda bir problemin ortaya konulduğunu ve kullanılan mitin bu problemi çözdüğünü savunmaktadır (Dağtaş, 2003: 95). Bu reklamda örtülü olarak sunulan problem; doğal içeriklere sahip olmayan 
ürünlerin kullanılmaması, bunun yerine "biz size \%100 doğal olan, doğadan aldığımız güçlü içerikleri barındıran bir ürün sunuyoruz" mesajını ileterek bu doğallık mitiyle çözümü de sunmaktadır. Yine bu doğrultuda ürünün doğal olma özelliğinden yola çıkılarak reklamın tüketim kültürüne sağladığı katkı ortadadır. Böylelikle tüketici doğal, katkısız ürün kullandığını fark ederek kendini doyuma ulaştıracaktır. Bu doyuma ulaşması için de bu ürünü satın almak durumundadır. Reklamlar kullandıkları bu mitik anlamlarla tüketiciyi satın almak için ikna etmeye çalışmaktadır.

Bu duruma bir örnek de Douglas ve Isherwood'un çalışması (1980) verilebilir. İkili, mallardan aldığımız hazzın fiziksel tüketimle ancak kısmen ilişkili olup, aynı zamanda birer damga olarak kullanılmalarıyla hayati bir bağlantısı olduğunu savunur; söz gelimi aldığımız ürünlerin isimlerini başkalarıyla paylaşmaktan zevk almaktayız (Aktaran, Featherstone, 2013: 46). Başka bir ifadeyle, ürünleri itibar kazanmak, duygusal haz elde etmek, statü sahibi olmak gibi sebeplerle tüketerek kapitalist meta üretiminin genişlemesine katkıda bulunmuş olunmaktadır.

\subsubsection{Sevil Kozmetik Mağazası Ürününün Reklam Analizi}

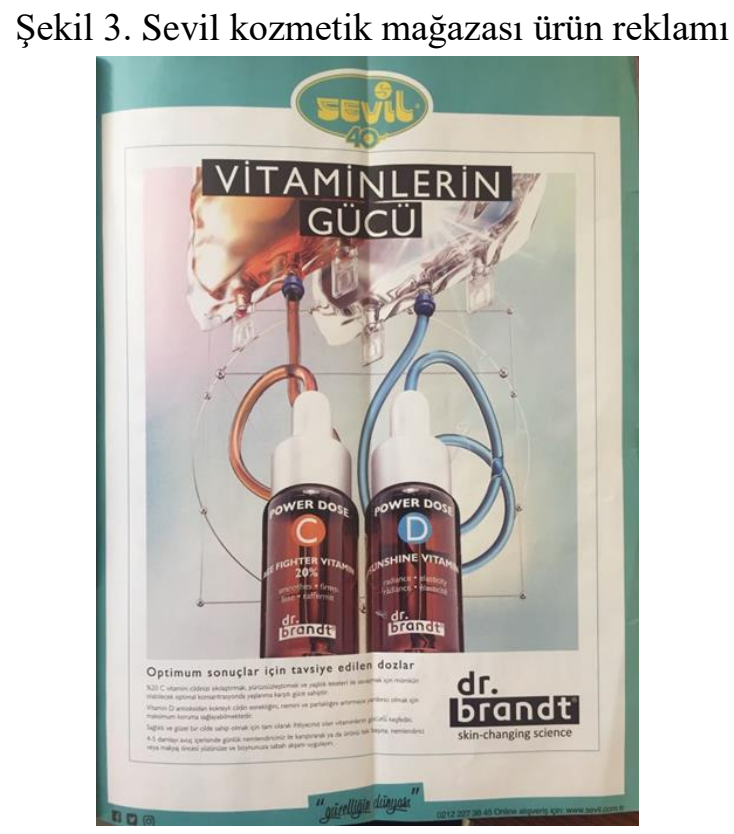

Gösterenler: Reklam, Cosmopolitan dergisinin Kasım 2016 sayısında yer almaktadır. Reklamda bulunan gösterenler şunlardır: Reklamın sloganı, metin, web adresi, yeşil şeritler, ürün görseli, serumlar, logolar, ikonlar ve beyaz zemin. Reklamda ağırlıklı olarak kullanılan renkler beyaz ve yeşildir. Bu tercihin firmanın kurumsal renginin yeşil olmasından kaynaklandığı söylenebilir. Gönderge Sistemleri:Gençlik, güzellik.

Mit: Gençlik miti, bilim miti, güzellik miti.

Reklamın Philps ve McQuirre'in Tipolojisine Göre Metafor Türü: Görsel figürlerin bağlantıs1 kategorisinde yer alan, birleştirme metaforu kullanılmıştır. "PowerDose cilt gençleştirici üründe bulunan içerikler, serum içinde bulunan vitaminlerle ilişkilidir" şeklinde formüle edilmiş, ürün ile benzettiği nesne birleştirilmiştir. Ürüne bu benzetim aracılığıyla vitamin gibi güçlü özelliği atfedilmiştir.

Analiz: Reklam, dr.brandt markasının PowerDose cilt gençleştirici kozmetik ürünüdür. Reklamı yapılan ürünün sloganı "Vitaminlerin gücü" ifadesidir. Okuyucuya bu kozmetik ürünün vitaminlerin gücünden elde edildiği bilgisi bu sloganda verilmiştir. Aynı zamanda, reklamın alt metninde üründen etkili sonuçlar elde etmek için kullanım tavsiyelerini içeren 
bilgiler yer almaktadır. Reklamın sol alt köşesinde twitter, instagram ve facebook ikonları kullanılarak okuyuculara 'Sevil' markasının sosyal medyada da hesapları olduğu belirtilmiştir. Yine aynı alanda sağ alt köşede firmanın telefon ve web adresi gibi iletişim bilgileri yer almaktadır. Firmanın kendi sloganı "güzelliğin dünyası" soft bir yazı fontuyla altta ortada yer almaktadır. Soft yazı fontunun tercih edilme sebebi, firmanın bünyesinde yer alan markaların ve bu markaların ürünlerinin zararsız ürünler olduğu düşüncesi olabilmektedir. Barthes nesnelerin, görüntülerin anlam taşıdıkları fakat bu anlamların tek başına bağımsız var olmadıklarını, her görsel göstergenin dille karıştığını belirterek sinemada, reklamda, fotoğraflarda anlamın böyle pekiştiğini savunmaktadır (Barthes, 1999: 87). Buna göre reklamda, etkili bir gösterge oluşturmak için hem görsel öğeye hem de dilsel öğeye ihtiyaç vardır. Bu bağlamda da, görsel metafordan ve dilsel retorikten yararlanılmaktadır. Reklamda kullanılan görsel ve dilsel öğeler incelendiğinde; reklamın görselinde ürünün kendisi gösterilmekle birlikte ürüne bağlanan iki serum yer almaktadır. Ayrıca ürünün arka planında kare, ters üçgen gibi figürlerde yer almaktadır. Bunlar Barthes'ında (1996: 198) belirttiği gibi ilk, doğal, görünen anlam olduğu için düz anlamdır. Yan anlam ise ikincil, ideolojik anlamı ifade etmekte ve mit olarak işlev görmektedir. Reklamın yan anlamsal analizine baktığımızda, kullanılan görsel ve dilsel öğeleri bir arada incelemek gerekir. Serum tıpta, insanlar hastalandığında kullanılan en etkili kısa sürede tedavi eden bir yöntemdir. Reklamın görselinde yer alan biri turuncu diğeri açık mavi serum iki ürüne de bağlanmıştır. Turuncu renk, canlılığı, dinamizmi ifade eden sıcak bir renktir. Açık mavi ise, huzur verici, rahatlatıcı bir renktir. Reklama ait alt metinde de açık mavi renge sahip ürünün cildin parlaklığını, esnekliğini artıran özelliğe sahip olduğu belirtilmiştir. $\mathrm{Bu}$ renkler kullanılarak da ürüne anlam aktarımı yapılmıştır. Buradaki yan anlamın, sloganda da yer aldığ gibi, serumun güçlü iyileştirici etkisinin ürüne atfedilmesidir. Bu iki üründe de güçlü serum etkisinin olduğunun, hem ürün içerisinde bulunan vitaminle hem de serumdan gelen vitaminle ürünün iyileştirici, düzeltici etkisi pekiştirilmiştir. Reklamın alt metninde iki ürününde kullanılarak yaşlanmaya karşı savaşacağını ve cildi pürüzsüzleştirip parlaklığını artıracağı bilgileri verilmiş, böylelikle bu ürünü kullanırsanız daha genç daha canlı bir cilde sahip olacaksınız düşüncesinden hareketle gençlik miti tüketiciye aktarılmıştır. Görsel olarak bilim mitine ürünün arka planında yer alan ters üçgen gibi şekillerle gönderme yapılmıştır. Bilim miti kullanılarak tüketiciye, bilimsel olarak da onaylanan bir ürün olduğu bilgisi iletilmeye amaçlanmıştır. Böylelikle bu mitleri kullanarak tüketiciyi ikna edip satın alma sürecine götürecektir.

Tüketim kültürünü, Barthes'ın deyimiyle çağdaş mit üretim alanı olarak görmek mümkündür (Dağtaş, 2003: 81). Günümüzde de reklam, bu mit üretme sürecinde başat rol oynamaktadır. Reklam bu yolla kültürün değerlerini ve mitlerini kullanarak, ürünleri değil, reklamlar aracılığıyla oluşturulan göstergeleri satmaktadır.

Tüketiciler, ürünleri ve markaları satın alıp tüketirken bunların ekonomik, teknolojik, işlevsel yararlarından çok, taşıdıkları ve aktarabildikleri sembolik anlamlara yönelmektedirler. Ürünün sadece 'ne yapabileceği' değerlendirmesinin yanında 'ne anlama geldiğini' de dikkate almaktadırlar (Odabaşı, 2013: 95). İncelenen reklamda da benzer durum söz konusudur. Reklam tüketiciye bu ürünle "güzelleşebilirsiniz" vaadinin yanında, dr.brandt ürünlerini kullanarak da 'bir statü sahibi olabilirsiniz' mitini yan anlamsal olarak iletmektedir. Zira dr.brandt ürünleri fiyatı gereği alt kesim ve orta kesime değil, elit kesime hitap eden ürünlerdir. Şayet bu markanı ürünlerini kullanırsanız elit kesimde olduğunuzun bir göstergesi olabilir, böylelikle çevrenize bu şekilde bir imaj iletmiş olursunuz. 


\subsubsection{Dermalogica Markasının Reklam Analizi}

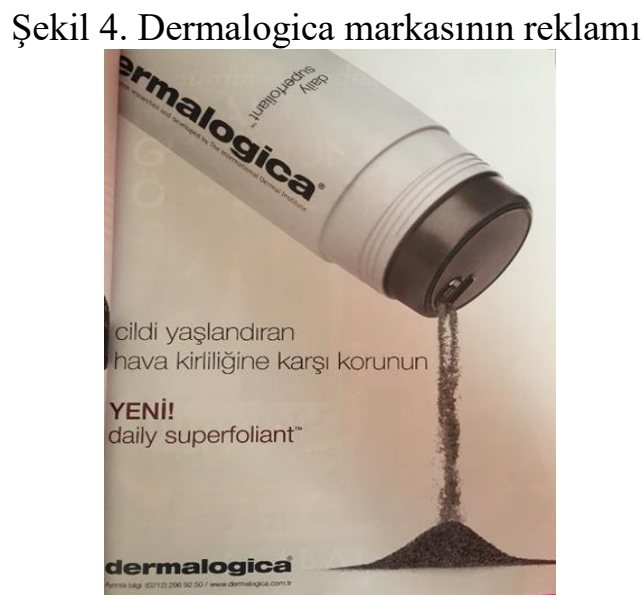

Gösterenler: Reklam afişi, Cosmopolitan dergisi Nisan 2017 sayısında yer almaktadır. Tasarımda bulunan gösterenler şunlardır; Başlık, beyaz zemin, logo, iletişim bilgileri, ürün görseli ve kirdir.

Gönderge Sistemleri: Korunmak, gençlik.

Mit: Kirliliğe karşı korunarak gelen gençlik miti, gençlik mitiyle birlikte beğenilme miti.

Reklamın Philps ve McQuirre'in Tipolojisine Göre Metafor Türü: “A, B gibi değildir” şeklinde formüle edilen "Zıtlık/Birleştirme" metaforu kullanılmıştır. A (ürün görseli) ve B (hava kirliliği) öğesi reklam içerisinde grafiksel olarak birleştirilerek gösterilmektedir.

Analiz: Reklamda, Dermalogica günlük koruma kreminin tanıtımı yapılmaktadır. Reklamın sloganı "cildi yaşlandıran hava kirliliğine karşı korunun" ifadesidir. Tasarımda ürünün 'yeni' olduğu bilgisi de okuyuculara iletilmektedir. Markanın isim logosu reklam afişinin sol alt köşesinde ve ürünün üzerinde yer almaktadır. Sol altta yer alan logonun hemen altında hedef kitlenin detaylı bilgiye ulaşması için telefon numarası ve web adresi yer almaktadır. Bunlar reklamın düz anlamlarıdır. Çalışmanın yan anlamlarını irdelemek gerekirse, ürünün görselinin kullanıldığını ve ürünün içerisinden başlıkta da belirtildiği gibi 'kirlilik, hava kirliliği’ nin döküldüğü görülmektedir. Burada iki farklı görsel öğe birleştirilerek metafor oluşturulmuştur. $\mathrm{Bu}$ kullanımla okuyucuya iletilmek istenen mesaj şöyledir: "bu ürünü kullanırsanız cildinize bulaşmış olan hava kirliliği yüzünüzden kayar gider". Günlük hayatta cildimizin kirlenmesine sebep olan etkenlerden biri de hava kirliliğidir. Ürünle birlikte "hem cildinizi gençleştirin, hem de kirlilikten arının" vaadi verilmektedir. Reklam burada aynı zamanda gençleşme mitini de kullanmaktadır. Reklamlarda mitler, ürünün ya da hizmetin kullanımıyla giderilecek çelişkilere değinir. Chapman (1983: 167) reklam metinlerinin analizinde, ikili karşıtlıklar ve bu karşıtlıktan doğan çatışmayı çözen mitsel bir içerik sergilediğini belirtir. Bunu bu reklam çalışmasında da açıkça görülmektedir. Burada da yaşlanma/gençlik ikili karşıtlığından yararlanılarak, "şayet genç bir cilt istiyorsanız bu ürünü kullanarak çözüme ulaşabilirsiniz" mesajını iletmektedir. Böylelikle, mitlerdeki çelişkilerden yola çıkılarak çözümde ortaya konulmuş olur. Krem 'daily' yani günlük kullanılabilecek bir kremdir. Tasarımda ağırlıklı olarak kullanılan renk beyazdır. Beyaz rengin psikolojik çağrışımı saflık ve temizlik kavramlarıdır. Üründe cildi temizlediğini, koruduğunu belirttiği için, bu renk tercihinin yapıldığg söylenebilir. 


\subsubsection{Cosmopolitan Dergisi Sayfa Tasarımı Analizi}

Şekil 5. Cosmopolitan Dergisi sayfa tasarımı



Gösterenler: Sayfa tasarımı, Cosmopolitan dergisinin Nisan 2017 sayısında yer almaktadır. Sayfa tasarımı dergide güzellik bölümü için ayrılan sayfaların kapağı niteliğindedir. $\mathrm{Bu}$ sayfa tasarımının değerlendirmeye alınma sebebi, kozmetik modasıyla ilgili olması ve tasarımda metafor kullanılmasıdır. Tasarımda bulunan gösterenler şunlardır; Başlık, metin, sarı zemin, rimel firçası ve ürün görselidir.

Gönderge Sistemleri: Vurucu bakışlar.

Mit: Doğru seçilen rimelle etkileyici, silah gibi vurucu bakışlar, güzellik miti, beğenilmek miti.

Reklamin Philps ve McQuirre'in Tipolojisine Göre Metafor Türü: Görsel figürlerin bağlantısı kategorisinde yer alan, yerine imaj koyma metaforu kullanılmıştır. Kullanılan rimel firçası görseli ile silah arasında bir benzetme yapılmıştır. Ürünü benzettiği nesne (silah) yerine kullanılmıştır.

Analiz: Sayfa tasarımında, rimel seçiminin önemli olduğuna vurgu yapan bir çalışma yer almaktadır. Zeminde kullanılan sarı renkle ürünler ön plana çıkarılmıştır. Ayrıca ürünlerin gölgesi sarı ışık sayesinde duvara yansıtılarak mistik bir hava yakalanmıştır. Çalışmanın başlığı 'güzellik'tir. Tasarımın sloganı "Silahınızı seçin" ifadesi olup, sloganın hemen altında sloganla ilgili detaylı bilgi tüketiciye aktarılmıştır. "Şayet tek tek ayrılmış uzun kirpikler istiyorsanız silikon firçaları, dolgun ve kıvrık kirpikler istiyorsanız kıl firçaları kullanın bilgisi" bu alt metinde verilmiştir. $\mathrm{Bu}$ çalışmada dilsel metafor aracılığıyla görsel metafora anlam yüklenmiştir. Başka bir ifadeyle, rimel seçiminin önemi "silahınızı seçin" dilsel metafor öğesi kullanılarak, rimelin bir silah gibi vurucu, etkileyici olduğu miti aktarılmaktadır. Tüketiciye nasıl ki silah aracılı̆̆ıyla bir insanı vurabilir, yok edebilirsiniz aynı şekilde silahın bu özelliğinden yola çıkılarak dolaylı anlatım yapılarak, "seçtiğiniz rimelle de isteğiniz kişiyi bir kurşun değmiş gibi etkileyebilirsiniz" mesajının iletilmesi amaçlanmıştır. Yine burada güzellik miti kullanılarak, "şayet etkileyici bakışlar istiyorsanız -beğenilmek istiyorsanız-'rimel' kullanın" denilmekte ve yine tüketim kültürüne hizmet edilmektedir. Tasarım, günümüzde kullanılan modern mitlerden beğenilme ve güzellik mitini kullanarak, ürünü satın almaya yönlendirmektedir. Barthes yan anlamı 'mit' olarak adlandırmakta, mitin iletilmek istenen ideolojik anlamı doğallaştırdığını belirtmektedir. Bu çalışmada da kullanılan metaforlar adeta 
gündelik pratiklerle iç içe girmiş, doğallaşmıştır. Böylelikle tüketici/ hedef kitle verilen yan anlamları, ideolojik anlamları herhangi bir süzgeçten geçirmeden kabul eder. $\mathrm{Bu}$ da mitin yukarıda bahsedilen doğallaştırıcı, masumlaştırıcı özelliğinden kaynaklanmaktadır.

\section{Sonuç}

Reklam, tüketicilerin karşısına kitle iletişim araçları aracılığıyla kontrol edilemez, bir tanıtma ve ikna etme aracı olarak çıkmaktadır. Reklamlar aracılığıyla yeni hayat tarzları sunulur. Reklamlar da yeni ürünlerin tanıtımını yaparken bu hayat tarzlarını kullanır. Aslında, yeni olarak gösterilen ve yüceltilen herşey, aynılı̆̆ 1 içinde barındırmaktadır. Bu yenilik ve değişimler kar güdüsünün değişimiyle doğru orantılı olup, bu sürecin bir maskelemesi olarak karşımıza çıkmaktadır. Reklamlar aracılığıyla sunulan bu 'yeni'ürünler ve hayat tarzları modern mitlerle güçlendirilir. Reklamlarda çekici hayat tarzları gösterilmekte, bireyler bir ürünü ihtiyaç duydukları için değil, reklamda oynayan karakterler veya ünlü kişiler gibi olmak, o reklamdaki hayat standardına sahip olmak için satın almaya yönelirler. Bir başka deyişle, bireyler etrafındakilerle iletişim kurmak için, bu imgesel alışverişi kullanır. Reklamlarda kullanılan gösterilenler, yeni istek ve arzular yaratmakta ve bireyi belli bir markayı satın alarak bu arzularını tatmin edebileceği hissi yaratılmaktadır. Reklam mesajlarında işlenen bu yeni hayat tarzları modern mitler ile desteklenmektedir.

Reklamlarda tanitılan ürün vb. insanlara haz verme vaadinde bulunduğundan dolay1, tüketim sorunları çözme mekanizması haline gelir, doğallaşır. Bireyler, tüketerek 'statü' ve 'prestij' sahibi olacaklarını düşünerek tüketirler artık. Bireyler üst sınıfların üyesi gibi görünmek için tüketmeye devam ederler. Böylece, metalar bireylerin ihtiyaçlarını karşılamanın ötesinde onların imajının da bir göstergesi haline gelir. Yani, tüketim kimlik oluşturucu bir unsur olarak karşımıza çıkar. Başka bir ifadeyle, insanlar kendilerini mallarla, ürünlerle, yani metayla özleştirerek bunlardan kendilerine güç aktarımı yapıp, bu ürünlere sahip oldukça güç kazanacaklarını ve böylelikle kendilerini çevrelerine kanıtlayacaklarını düşünürler. Marx (1980: 227), "Üretim aynı zamanda tüketimdir" derken kapitalizmin tüketim üzerine kurulduğuna, insanların nasıl giderek tüketimin tutsağı haline getirildiklerine tüketerek ancak kendi varoluşlarını anlamlı hale getirmeye çalıştıklarına gönderme yapar (Güngör, 2013: 139).

Çalışmada incelenen reklamların değerlendirmesini yapıldığında da, yukarıda bahsedilen bireye anlam yükleme, yeni imajlar kazandırma, arzulanan şeylerin tatmini, güç sahibi olma, hazcı tüketim gibi anlamlardan hareketle reklamların oluşturulduğu görülmektedir. $\mathrm{Bu}$ anlamlar reklama yüklenirken de sıklıkla metafora, metonomiye, mecazi söyleme, yan anlama göndermeler yapılmıştır. Böylelikle reklamlara kültürel mitler eklenerek, reklamlar daha ilgi çekici hale getirilmeye çalışılmış ve kullanılan mitler aracılığıyla bireyleri tüketime yönlendiren, bireylere çeşitli vaatlerde bulunarak onlara mutlu olmanın yollarını gösteren birer araç olarak kullanılmıştır.

Cosmopolitan ve Elle dergisi içerisinde yer alan reklamların genel bir değerlendirmesi yapıldığında Cosmopolitan dergisinde Elle dergisine oranla daha fazla metafor içeren reklamların kullanıldığı görülmektedir. Her iki derginin her sayısında metafor içeren reklamlar ağırlıkta olarak kullanılmıştır. Bu anlamlar aktarılırken çeşitli görsel kodlardan yararlanılmış (görsel metafor, dilsel metafor, yan anlamlar gibi) ve böylelikle reklam çalışmaları aracılığıyla tüketiciye ürün satın alındığı takdirde sahip olunabilecek mutluluk, tatmin, farklı hissetme, bir sorunu çözme gibi vaatlerin gerçekleşebileceği belirtilmiştir. Aynı zamanda incelenen reklamlarda bu anlamlar yaratılırken, subliminal mesajlara da sıklıkla başvurulduğu görülmüştür. Ürün satışını artırabilmek için kullanılan subliminal mesaj teknikleri ile tüketici ihtiyacı olmasa bile o ürünü satın alabilir veya aynı ürünün farklı markalarından bu tip mesajların sunulduğu markayı tercih edebilir. İncelenen reklamlarda da, bu bilinçaltına özellikle 'güzellik ve gençlik' ile seslenen pek çok imgenin kullanıldığı görülmüştür. Bireylerin dolayısı ile toplumun tüketim toplumu haline gelmesine destek olan subliminal mesajlar, toplumlar için 
tehdit oluşturabilecek niteliktedir diyebiliriz. Bu tür mesajlara farkında olmadan maruz kalan tüketiciler mesajı gönderen kaynağın istediği yönde hareket etme sürecine girmiş olacaklardır.

\section{Kaynakça}

Altunışık, R., Coşkun R., Bayraktaroğlu S., Yıldırım E. (2010). Sosyal Bilimlerde Araştırma Yöntemleri, 6. Basım, Sakarya: Sakarya Yayıncılık.

Ang, S., Lim, H., Ching, A. (2006). The Influence Of Metaphorsand Product Type On Brand Personality Perceptions And Attitudes, Journal Of Advertising, 35 (2): 39-40.

Aydoğan, F. (2009). Tüketim Kültürünün Gölgesinde Kentler, Marmara Üniversitesi İI.I.B.F Dergisi, 27 (2), s. 203-215.

Aytaç, Ö. Tüketimcilik ve Metalaşma Kıskacında Boş Zaman, Kocaeli Üniversitesi Sosyal Bilimler Enstitüsü Dergisi, 11 (1), 2006, 27-53.

Bat1, U. (2007). Reklamlarda Retorik Figürlerin Kullanımı, Marmara Üniversitesi Sosyal Bilimler Enstitüsü Dergisi.

Barthes, R. (1996). Çağdaş Söylenler. İstanbul: Metis Yayınları. (1957).

Barthes, R. (1999). Göstergebilimsel Serüven. (Çev: Mehmet Rıfat, Sema Rıfat). İstanbul: Yapı Kredi Kültür Yayıncılık.

Batı, U. (2013). Reklamın Dili. İstanbul: Alfa Yayınları.

Bauman, Z. (1999). Çalışma, Tüketicilik ve Yeni Yoksullar, (Çev: Ümit Öktem) İstanbul: Sarmal Yayınevi.

Caroll, N. (1996). A Note on Film Metaphor, Journal of Pragmatics. [Film Metaforu Üzerine Not] Vol: $26,(6): 809-822$.

Chapman, S. ve Garry E. (1983). Myth In Cigarette Advertising and Health Promotion

Language, Image, Media, (Eds) der. H. Davis ve P. Walton. Londra: Basil Blackwell, (pp.167-185).

Çınar, N. (2009). Reklamda Kullanılan Görsel Metaforların Reklamın Beğenirliği Üzerine Etkisi, Yayımlanmamış Yüksek Lisans Tezi, Anadolu Üniversitesi Sosyal Bilimler Enstitüsü, Eskişehir.

Dağtaş, B. (2003). Reklam, Kültür, Toplum. Ankara: Ütopya Yayınevi.

Elden, M. ve Okat Özdem, Ö. (2015). Reklamda Görsel Tasarım. İstanbul: Say Yayınları.

Elden, M. ve Yeygel, S. (2006). Kurumsal Reklamın Anlattıkları. İstanbul: Beta Yayınları.

Featherstone, M. (2013). Postmodernizm ve Tüketim Kültürü. (Çev: M. Küçük). İstanbul: Ayrıntı Yayınları.

Fiske, J. (2014) Illetişim Çalışmalarına Giriş. (Çev: Süleyman İrvan) Ankara: Pharmakon Yayınevi.(1982).

Forceville, C. Pictorial Metaphor in Advertisements, Metaphor and Symblic Activity. 9(1): 1-29.

Foucault, M. (1986). Of Other Spaces. Diacritics 16:22-27.

Goatly, A. (1997). The Language of Metaphors. Londonand New York: Routledge.

Güz, H. (2000). Reklamın İki Yüzünün Psikolojik, Ekonomik ve Toplumsal Çerçevede

Değerlendirilmesi, Selçuk Üniversitesi İletişim Fakültesi Dergisi, 1 (2): 135-146.

Hall, S. (2005). Kodlama- Kodaçımlama. Yiğit Yavuz (Çev), Şahinde Yavuz (Der). Medya ve İzleyici: Bitmeyen Tartışma. Ankara: Vadi Yayınları. 
Kaya, K. ve Oğuz, N. Z. (2010). Üniversite Gençliğinin Alışveriş Tercihlerinde Tüketim Kültürünün Rolü, Sdü Fen Edebiyat Fakültesi Sosyal Bilimler Dergisi, 22: 147-164.

Kırılmaz, H. ve Ayparçası, F. Modernizm ve Postmodernizm Süreçlerinin Tüketim Kültürüne Yansimalar1. Insan\&Insan, 8: 32-58.

Küçükerdoğan, R. (2005). Reklam Söylemi. İstanbul: Es Yayınları.

Küçükerdoğan, R. (2011). Reklam Nasıl Çözümlenir? Reklam Illetişiminde Göstergeler ve Stratejiler. İstanbul: Beta Yay.

Lyotard, J. F. (1997). Postmodern Durum. (Çev: Ahmet Çiğdem). İstanbul: Vadi Yayınları.

McQuarrie, E. ve Mick, D. G. (1996) Figures of Rhetoric in Advertising Language Journal of Consumer Research, 22: 424-438.

McQuarrie, E. ve Mick, D. G. Visual Rhetoric in Advertising: Text-Interpretative, Experimental and Reader-Response Analyses Journal of Consumer Research. 26: 37-54.

Messaris, P. (1996). Visual Persuasion: The Role of Images in Advertising. London: Thousand Oaks: Sage.

Mick, David G. (1992). Levels of Subjective Comprehension in Advertising Proessingand Their Relationsto Ad Perceptions, Attitudesand Memory Journal of Consumer Research. Vol:18, No:4.

Mutlu, O. “Arzunun Devrimi ve Medya”, Selçuk Üniversitesi İletişim Fakültei, Dergisi, 4 (1): $38-41$.

Odabaş1, Y. (2013). Tüketim Kültürü: Yetinen Toplumdan Tüketen Topluma. İstanbul: Sistem Yayıncilik.

Odabaşı, Y. (2014). Postmodern Pazarlama. İstanbul: MediaCat.

Phillips, B. J. (1997) Thinking into It: Consumer Interpretation of Complex Advertising Images Journal of Advertising, 26 (2): 77-87.

Ramacetti, D. (1995). Başarılı Reklamın Sırları. (Çev: Rengin Erdoğmuş). İstanbul: Özel Basımevi.

Refaie, Elisabeth. (2003) Understanding Visual Metaphor: TheExample of Newspaper Cartoon Visaual Communication. 2 (1): 75-95.

Richards, J. I. ve C. M. Curran (2002). Oracles on Advertising: Searchingfor a Definition, Journal of Advertising, 31(2).

Sopory, P. ve Dillard, J. P. (2002). The Persuasive Effects of Metaphor: A Meta-Analysis Human Communication Research, 28 (3): 382-419.

Topçuoğlu, N. (1996). Basında Reklam ve Tüketim Olgusu. Ankara: Vadi Yayınları.

Williamson, J. (2001). Reklamların Dili: Reklamlarda Anlam ve İdeoloji. (Çev: Ahmet Fethi). Ankara: Ütopya Yayınevi. (1978).

Yanıklar, C. (2006). Tüketimin Sosyolojisi. İstanbul: Birey Yayınları. 